\title{
Political Theory within Political Science
}

Ross J. Corbett, Northern Illinois University

ABSTRACT This article addresses Andrew Rehfeld's attempt to ensure a place for political theory within political science, which he does partly by showing how political theory fits into a defensible definition of political science and partly by excluding much political theory from the discipline in order to safeguard the rest. His account of what the discipline should comprehend is overly narrow, however, and does not serve the interests of the sorts of political theory he strongly believes are worth doing. I argue instead that political science must be defined by its subject matter alone, and that political theory's contribution to this subject matter must be defended.

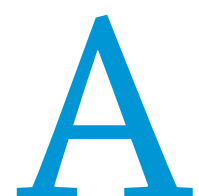

ndrew Rehfeld's article entitled "Offensive Political Theory" attempts to ensure a place for political theory within political science (Rehfeld 2010). ${ }^{1}$ Given the letters sent to Pennsylvania State University in support of political theory, which he rightly characterizes as impractically defensive, Rehfeld goes on the offensive, articulating a vision of political science that is broad enough to encompass some political theory. This offense sacrifices the rest of political theory, a sacrifice that Rehfeld presumably hopes will be limited to its exclusion from "real" political science, while allowing it to survive in some interdisciplinary program or other.

However, Rehfeld's account of political science is overly narrow. He ends up excluding more than just a few aspects of political theory and freeing his quantitative colleagues from the necessity of teaching statistical methods. Fitting political theory within a paradigm in which falsifiability is king is not so much a matter of clarifying what political theory does but of putting theory through a series of contortions. Rehfeld insists upon his conception of what political science must be by reference to the university structure, but his account of that structure is not persuasive. Political science is defined by its subject matter, not by an overly stylized view of science. Political theory in its various forms must be justified as a subfield by demonstrating that it contributes to our understanding of that subject matter.

\section{REHFELD'S POLITICAL SCIENCE}

Rehfeld presents three criteria for membership in the discipline of political science. First, that activity must be research, as opposed to some other sort of activity. Second, it must deal with political phenomena, by which he means those situations that involve the use or potential use of force. Third, this research must not violate the assumptions of science-by which he means Comtian social science, in which researchers discover facts about an observerindependent world through the falsification of hypotheses. As a

Ross J. Corbett is an assistant professor of political science at Northern Illinois University. He conducts research on emergency powers, American constitutionalism, and the history of political philosophy. He is the author of The Lockean Commonwealth (State University of New York Press, 2009) and articles on Locke, Aristotle, and the problem of crisis government. He can be reached at rcorbett@niu.edu. result, conceptual and normative theory are justified as political science (albeit with some problematic arguments regarding the role of "falsification" in these programs), while advocacy, most explanatory and interpretive political theory, and textual and historical political theory are denied any claim to departmental resources.

\section{The Emphasis on Method}

One problem of this argument stems from Rehfeld's assertion that political science is not just research regarding politics, but rather is scientificresearch regarding politics. This claim implies that a good deal of core "political studies" research should be conducted in another department. Rehfeld is explicit that he would not be surprised if what he calls scientific methods were inadequate for providing a comprehensive understanding of political phenomena and would have to be supplemented by more "humanistic" methods (474). He simply thinks that this methodological split should exist at an institutional level: there should not be one place where politics is studied, but rather two (or more) places where it is studied in different ways. He claims that this arrangement respects the division between the social sciences and the humanities.

The argument that political science must be defined by its methodology as well as its subject matter because it is a social science and not one of the humanities is not a compelling portrait of the distinction between the social sciences and the humanities. Rehfeld claims that acceptable research in the humanities involves assembling persuasive and coherent arguments, but does not involve subjecting them to the demands of falsifiability, as in the social sciences. The humanities are valuable insofar as they err on the side of not discounting too hastily something that might potentially be true, while the social sciences jealously guard against accepting something that might perhaps be false (474). Rehfeld's methodological claim is neither an accurate description of the differences between the social sciences and the humanities, nor a persuasive argument on its own premises.

On one hand, as Rehfeld states it, the division boils down to the fact that the social sciences are rigorous while the humanities are not, with the humanities accepting things that are plausible without sufficient regard for whether they are true. This accusation has often been hurled in their direction, but with the aim of 
discrediting what is done in the humanities altogether, and not as a neutral description of them. On the other hand, Rehfeld does not wish to discredit the parts of political theory that he would define as the "humanistic" study of political phenomena; he engages in those parts himself on occasion. Therefore, one must wonder why the same scholar should not engage in both pursuitsthat is, why there should be an institutionalized division of labor in which some scholars are concerned with developing possible interpretations and others with winnowing them down. More important, one must wonder why these approaches should be housed in separate academic disciplines rather than be compelled to speak to each other's work, as membership in the same discipline would require.

I also cannot say that the humanities adopt the same view of their division from the social sciences. Certain historians believe that they have refuted (or as Rehfeld would have it, "falsified") what some political scientists say about John Locke, for example (cf. Dunn 1969; Yolton 1958; also see Ashcraft 1986). In turn, political scientists have conducted further research attacking these historians' methods, evidence, reasoning, and so on (cf. Pangle 1988; Waldron 2002; Zuckert 2002). The historians' response is not gen- insisting that political theory be analogous to a particular method when that method is not defended as the only rigorous mode of research.

\section{Political Theory as Positivist Social Science}

Rehfeld attempts to equate logical positivism with social science positivism to show how some political theory can accord with the social science requirement for falsifiability. The survival of those parts of political theory that Rehfeld marks for survival, however, is not served by compelling them to speak the language of positivism. And to someone focused on empirical falsifiability, there is something artificial about saying that one "falsifies" a theory of justice by showing it to be contradictory, question begging, or at odds with something else in which we have greater confidence (e.g., biological facts). Moreover, one does not attempt to falsify a hypothesis experimentally until that hypothesis has been well stated. At a minimum, a hypothesis must be shown not to be contradictory before one attempts to falsify it. Showing that a hypothesis is incoherent is not to falsify it as much as to say that experimental falsification is not even necessary. Consequently, Rehfeld does not actually bridge the gap between political theory

\section{Political science, too, is defined by its subject matter, and a criticism of political theory should be that it teaches us nothing about politics, not that it is not "science." A justification of political theory, conversely, should be that rigorous research into questions of its concern is possible, not that it is somehow analogous to a particular method. There is even greater justification for not insisting that political theory be analogous to a particular method when that method is not defended as the only rigorous mode of research.}

erally that they are not to be held to as high a standard of proof as political scientists are; indeed, the historians' critique of political scientists was the continuation of a movement within the discipline of history itself to increase its rigor, a movement that is now over four decades old (cf. Dunn 1968; Skinner 1969).

Moreover, the division that Rehfeld imagines as existing within political science is not mirrored in other disciplines. Classicists do not banish stylometric analysis to a separate classical science department because it admits too much falsifiability for a humanities discipline. Nor is there a rift between archaeologists and historians over the permissibility of interpreting ancient inscriptions or relying on radiocarbon dating in their respective fields.

We cannot say that the difference between the social sciences and the humanities is primarily methodological. Rather, a justifiable distinction between them must focus on their differing subject matter. Simply put, the social sciences study social behavior in various ways. Because human beings are social creatures, the humanities obviously cannot ignore society, but philosophy, literature, and foreign languages need not focus on social behavior to the same degree.

Political science, too, is defined by its subject matter, and a criticism of political theory should be that it teaches us nothing about politics, not that it is not "science." A justification of political theory, conversely, should be that rigorous research into questions of its concern is possible, not that it is somehow analogous to a particular method. There is even greater justification for not and the sort of activity cleaved to by some (though not all) other parts of the discipline.

To speak of "falsifying" political theory hypotheses gives the impression that theories are falsified by empirical data-an assertion that, if taken seriously, would limit what theorists could study beyond what Rehfeld hopes to preserve. (One can speak sensibly about falsifying interpretations of a text, since the text is there to be observed empirically, but this one facet of political theory that could be conducted with falsification in mind does not deal with politics, according to Rehfeld.) He notes, as an example, that equating legitimacy with public support does not track our intuitions about legitimacy. However, this is not really a matter of falsifying that definition of legitimacy. The fact that the objects of theoretical inquiry are "out there" or can be said to have an objective existence does not mean that theorists compare predicted behavior with experimental results. Or, in order for Rehfeld's argument about legitimacy to be an example of falsification, we would have to equate legitimacy with intuitions about legitimacy (which can be studied empirically). Rehfeld (rightly) wants to preserve the study of justice as a rigorous part of political science, but the approach that he advocates would in fact end up preserving the study of opinions about justice.

\section{The Challenge Presented by Empiricism}

Shoehorning some political theory into the mold of Comtian social science distorts the core disagreement over whether political 
theory can be rigorous or have a place within a research-oriented discipline devoted to the study of politics. This core disagreement actually concerns the question of empiricism, not positivism. If we wish to make the case that political theory belongs in political science, what is needed is an appreciation that (1) not all interesting political questions can be answered by recourse to empiricist methods; and (2) political theory is amenable to a certain kind of rigor, such that it would constitute research rather than self-expression.

Rehfeld argues that the political theory worth saving is properly scientific-in the sense that it conforms to Comtian social science-because it acknowledges an objective reality that it attempts to discover. There is such a thing as justice, for example, and normative theorists are social scientists because they seek to discover justice. He does not address the claims of those thinkers who doubt the existence of an objective thing called "justice" that can be discovered, except to say that these scholars deny a basic tenet of science.

It might perhaps be possible to argue that one is not engaging in "science" if one doubts the existence of an objective universe, but granting this would not suffice for an argument against political theory that calls objectivity into question. One might instead object that when the ontological foundations of a discipline are false or unfounded, the discipline should fall or be radically transformed, not that we must bear down and turn a blind eye to its inadequacies. One must accept certain ideas in order to study astrology, but there is no science of astrology, for the simple reason that the things that one must accept to practice it offend intellectual probity. If a significant portion of the discipline rests on dubious ontological commitments, it would seem appropriate to note and question these commitments, even if one is unable to point a way forward. I am not persuaded of the no-objectivepolitical-reality challenge to positivistic social science, but the argument that these questions are out of bounds seems even less persuasive.

Putting this question aside, however, Rehfeld misses the important distinction between a thing's objective existence and its ability to be objectively observed. Justice is not as readily detectable as voter turnout, for which (in principle) any disagreement should be traceable to flawed observation methods. Only in regard to such things would a truly value-neutral social science be possible.

The existence of observer-independent facts is not enough to sustain a positivistic social science. Rather, real value-neutrality would require that the clues to the truth about these observerindependent facts also themselves be observer-independent. It is one thing to say that there is an objective answer to the question "What is justice?" that does not depend on the idiosyncratic qualities of the person asking the question. It is quite another thing to say that the data analyzed in pursuing this question are readily apparent as long as you have the right data collection method. Rehfeld tries to save (some) political theorists by acknowledging that they too believe in truth. However, it is not the existence of objective reality, but the relationship of empirical observations to that reality that lies at the root of a value-neutral social science.

A defense of political theory as a part of the academic study of politics must confront this empiricist challenge, since political theory is impossible if political science must deal only with the readily observable. Because political theory cannot honestly represent itself as a positivistic social science (except insofar as every empiricist is a theorist before conducting his or her real research), political theorists must defend the existence of political phenomena that are not amenable to unreflective observation. We must further argue the more difficult point that it is possible to set a rigorous research program to investigate these phenomena. This latter point is more difficult to make because it asserts that while personal qualities affect the outcome of one's theorizing, that outcome is not merely the expression of one's personal qualities. This contention is, however, something that we must render plausible to our colleagues, in addition to establishing the existence of crucial political phenomena that cannot be researched using empiricist methods.

\section{Long-Term Effect on Political Theory and the Discipline}

Although Rehfeld sees great value in the political theory that he wishes to exclude from political science, his arguments are a recipe for its gradual elimination. He claims that these aspects of political theory are more properly classified as interdisciplinary studies. Only pure political theory should remain within political science. The rest should continue to be done, but not as a part of the discipline. This arrangement seems to neglect the prospects interdisciplinary studies have for survival. The effectual truth of his "not here" is "not anywhere."

An academic field is stable only if there are institutional structures in place regarding hiring, teaching, promotion, and so on (cf. the problems discussed in Klein 1996; Lattuca 2001; Rhoten and Parker 2004). This is true for both traditional disciplines and interdisciplinary subjects. Without an institutional home, interdisciplinary studies are just chance collaboration, left to the vicissitudes of personal encounters among faculty. Such collaboration can occur, but not with enough frequency to ensure a field's preservation. Moreover, who we train must be linked to what we do. If we no longer train students in that part of political theory that Rehfeld calls "interdisciplinary" rather than political science, then either we must hire professors who will not be expected to train graduate students, or else "interdisciplinary" political theory will fade away, since its practitioners will be unable to find jobs. Expelling a good deal of political theory from the political science discipline and expecting it to survive in some kind of interdisciplinary ethereality neglects harsh administrative realities.

The logic behind excluding what Rehfeld calls "interdisciplinary" political theory from political science is that interdisciplinarity requires composite disciplines to be kept separate. Otherwise, Rehfeld argues, we would not be mixing disciplines so much as creating a new one. While this logic is true in some technical fashion, the persuasive force of the argument is based on an intuition that the traditional disciplinary distinctions make sense and must be preserved without addition or alteration. On the contrary, however, the whole impetus behind interdisciplinary studies is that disciplinary boundaries can get in the way of research and we might thus need to break down some of those walls (cf. Klein 1996; Lattuca 2001). That is, the logic of interdisciplinary studies is directly contrary to the rules that Rehfeld would impose upon them.

So far, I have adopted Rehfeld's contention that much political theory is interdisciplinary, but that is not really the case. Or rather, political theory is no more interdisciplinary than political science as a whole. As I discuss in the following, the study of politics necessarily touches on issues dealt with in other disciplines as well (see Axelrod 2008). Political science also uses methods favored by other disciplines, so much so that we can speak of an "economic" approach to political science. What Rehfeld perceives to 
be political theory's unconscionable eclecticism is not peculiar to political theory.

Rehfeld's definition of political science is ultimately a political strategy rather than a principled argument. For example, he wants to avoid the necessity of making ontological assertions that there is an objectively discoverable political universe. Instead, he says only that one is not doing science if one does not accept such ontological assertions and that political theory that objects to these assertions is therefore not science (Rehfeld 2010, 473). He suspects that a comprehensive understanding of political phenomena would require both "social scientific" and "humanistic" methods (474). He seems to argue that we should accept the division of political studies into scientific and humanistic components because "political science" simply is going to be done. The discipline is moving in a Comtian direction, he reminds us (466-67). As a principled matter, however, this seems irrelevant-unless his argument is that our colleagues are moving in a Comtian direction whether we like it or not, and therefore we ought to submit before the new dispensation. Rehfeld does not claim that only Comtian social science can be rigorous enough to count as research. Some rigorous research on politics should not be done within political science, since this research does not fit with the activity of those who think that only the Comtian system fosters the sort of rigor necessary for the discipline. His piece is not an offensive on the part of political theory or an active defense so much as a strategic and permanent redeployment to the rear.

One might contest whether the discipline as a whole is actually moving in a Comtian direction. Public law has an empirical element, of course, but it is not wholly empirical. Both comparative politics and international relations are methodologically diverse. Our students and their parents would be shocked if we told them that American political development should not be a part of American politics, let alone political science. Battles may occur within the subfields, but this very fact demonstrates that the Comtian consensus that is sometimes claimed by scholars pushing this model of political research and to which Rehfeld appeals does not in fact exist.

In any event, an appeal to such a consensus that is made without a willingness to defend the epistemological and ontological presuppositions of that consensus is a political act. Such an appeal does not provide a reason to abandon the fight for a broader, principled conception of political science that admires the achievements and potential, while recognizing the limitations, of both empirical methods and ratiocinative methods.

\section{THE BREADTH OF POLITICAL SCIENCE}

It is difficult to define politics in a way that does not rely on strong theoretical commitments. Many definitions of politics actually describe the scholar's conception of legitimate politics-that is, what they think should pertain to politics. ${ }^{2}$

Rehfeld confronts this difficulty with a specific but diaphanous definition of politics as the sphere of human activity in which force against another human being is involved or has the potential to be involved. Many questions could be political under Rehfeld's definition, especially if political subjects need ultimately touch on force but need not do so at first or even second glance. Insofar as this is the case, his definition is unobjectionable, if somewhat artificial. People feel that they know what politics is-when they are acting as a citizen or statesman as opposed to a husband or tennis player-and then political scientists teach them that pol- itics has to do with force. People agree with this idea because it tracks their intuitive understanding well enough, if not always in an obvious manner. But the fact that people can be brought to agree with this definition establishes only that the presence of force or the potential for its application models politics; that definition cannot then be used to "correct" a person's more intuitive understanding of politics. In order to avoid this sort of problem, we may have to accept a vague definition of politics that relies on our intuitions in an unsatisfying way (or a way that is unsatisfying to theorists, at any rate).

While a definition of political science that focuses on the application of force on another human being could be rather broad, it is clear that Rehfeld holds a more narrow conception. For example, he claims that texts are not political phenomena, even considering the role that debates over the actual intentions of the framers of the U.S. Constitution play in American politics. It is true that much of the political theory that Rehfeld would place outside of political science proper has analogues in other departments. However, this argument against the propriety of studying them in political science seems false. Neat lines between disciplines could be drawn only if the objects of human inquiry itself were mutually exclusive; as an ontological proposition, this contention is implausible to the extreme. I do not think that the current university structure was intended to be or could be defended as the ossification of a particular and unstated metaphysical hypothesis. The study of politics is by its nature interdisciplinary.

\section{Accepting Political Science "Exceptionalism"}

However much Rehfeld objects to political science exceptionalism, political science really is an "exception" to the rules he sees governing the other disciplines. ${ }^{3}$ He notes that psychologists do not read Aristotle's meditations on the soul, nor do economists read Adam Smith to gain insights into the GDP. This observation may be true, but those fields are justified in ignoring the past because of their narrow focus, not because another field (history) also studies the past. Psychology, its name aside, is not the study of the soul, but is rather geared toward practice: producing measurable results in therapy, childhood education, and so on. Economics largely deals with people only to the extent that they interact regarding the exchange of goods and services. An individual's decision to make origami swans out of dollar bills rather than lighting cigars with them is in general irrelevant to economists, whose concern is only to track whether that individual has acquired, spent, or removed that money from circulation. ${ }^{4}$ While manic, one patient who suffers from bipolar disorder might exhaust his or her savings on drugs and another might read a book while driving cross-country, but these differences are irrelevant to the psychologist, who need only be concerned with whether lithium decreases the severity of manic and depressive episodes.

Politics, however, is not bounded in this way. Although political science focuses on a particular type of activity, it cannot bracket off aspects of human nature and thereby simplify the problem with which it wrangles. Because those individuals who triumph in the political arena are subject to fewer limitations than the average person, the full range of human motivations can be on display in a way that they are not in behaviors studied by other disciplines and in a way that is relevant to how people use force against each other. Questions about which institutions or norms might have reduced the influence of Savonarola's intolerant hatred 
or Cleopatra's seductive charm on the fate of nations are certainly political science issues, but Rehfeld asserts that we must be nothing more than passive consumers of other departments' research on why zeal and eros enjoy such influence, regardless of whether other departments are actually conducting satisfactory research in these areas. (If scholars do conduct this research themselves, they would cross a line into "interdisciplinary studies," which, according to Rehfeld, disqualifies them from claiming departmental resources.) While other social sciences might conceivably be able to ignore certain aspects of their subjects' behavior, insofar as these aspects do not affect their object of study, the numerous motivations for seeking power affect how that power is used.

The fact that politics can be affected by almost the whole range of human behavior and longings means that political science can legitimately encroach on other disciplines' "turf," just as these disciplines occasionally claim that their research speaks to questions of political concern. Because history matters politically, political science can be historical in a way that not all disciplines feel the need to be. The discipline can engage in even more wideranging research. Just because the social behavior of chimpanzees or capuchin monkeys is studied in departments of anthropology, economics, and psychology is no reason why it is an improper subject for political science (Alford and Hibbing 2004). Whether choices result from rational processes that would allow the construction of explanatory models around rational choice has been questioned in the fields of economics, neurology, and psychology, but that prior work does not mean that this hypothesis cannot be questioned by political scientists (MacDonald 2003; McDermott 2004; Quattrone and Tversky 1988; Schiemann 2007; Schildkraut 2004). Some justifications we give for our policy preferences imply that human behavior is malleable as a result of education; others affirm the relative stability of a robust, nontrivial conception of human nature. Political science is not simply informed by research into the existence of a "human nature" but can engage in this research on its own and even question what the existence of a human nature would mean (Doidge 2010; Hatemi, Medland, and Eaves 2009; Mansfield 2006). The introduction of liberal democracy into the Muslim world has been countered by claims that liberal democracy is un-Islamic. The contrary claim had been made that liberal democracy could be accepted by devout human beings (e.g., Locke 1983). It is not politically irrelevant to ask whether the individuals who made this second claim were perhaps disingenuous, or whether their arguments relied on claims that were accepted only by particular denominations of Christianity (Dunn 1969; Strauss 1953; Waldron 2002).

Yet because history is also examined in history departments, Rehfeld says that it cannot be political science. I do not think that he wishes to make the parallel claim that because (some) political theory is also conducted in (some) philosophy departments, it too cannot be political science. Nor do I think that he wishes to extend that argument to other subfields, surrendering their lines to economics, area studies, biology, social psychology, anthropology, or education and leaving those fields to fight over the exiled scraps of a political science that studies only what others are not currently interested in studying.

\section{No A Priori Exclusions}

Those suspicious of a broad understanding of political science are right to ask what is in principle excluded from the field. Rehfeld offers several absurd examples intended to reduce the persuasive- ness of a broad understanding of politics, such as whether music appreciation could be taught in political science.

It is curious, however, that both Plato and Aristotle conduct extended discussions of music in their political works, not so much for music appreciation's sake, but to explore the political importance of music. They included these discussions because of their belief that different styles of music affect the passions, which in turn form the basis of education, and that political society relies on its members' having received a particular education.

That is, Plato and Aristotle did not think they were writing about politics and music. Nor did Aquinas think he was writing about politics and theology. Nowadays, we often consider politics to be not only separate from questions of music and theology, but also completely uninvolved with them. This segregation is the result of historical arguments that claim that politics should be concerned only with material welfare and that the legitimate use of force should be blind to religious or even cultural questions. The heirs of this tradition transform statements about which questions should be politically relevant into statements about which questions are relevant.

What I mean by these remarks about Plato, Aristotle, and Aquinas is that modern intuitions about what is political are the result of an identifiable and somewhat accidental historical narrative. Close attention to the question of how people actually use force suggests that other factors-whose influence on politics liberal theories of legitimacy condemn-may be worth taking account of politically.

At the risk of alienating even more readers with an understanding of political science that seems incapable of excluding subjects a priori, I will push this claim further. Not only is this broader understanding of politics necessary if one desires to study the political phenomena that we Westerners find relevant in a relatively value-neutral way, but some scholars and philosophers make the more radical claim that politics itself is inherently historical. Some political proposals rely on a rejection of the current consensus on what is political. Some of these critics claim that we share an intuition about what politics is not because the answer is intuitive, but because we are so habituated to a particular answer that we have forgotten that there was even a question to be asked. This sort of claim clearly calls for evidence.

Someone making this claim would need to examine the history of political thought in order to corroborate their explanation of why we share this intuition about what is political. Moreover, because such a person argues that we should take another path, he or she must argue with those in favor of the path we are now following. If the question has really been forgotten-which is to say, if he or she lacks a contemporary opponent-then someone who makes this claim must argue with the original advocates of our current path, determine their arguments, defend his or her own understanding of their arguments against critics who counter that they said no such thing or had no such influence, and so on. Unless one is going to import all sorts of contestable and dubious political commitments into the very definition of political science, the fact that our colleague Plato is unfortunately no longer with us does not make serious engagement with his thought somehow less a matter of "political science" than an engagement with Rehfeld on the meaning of representation.

Rehfeld claims that texts are not political phenomena. Yet justifications for political activity must certainly be political phenomena. His point must be that old texts that are not obviously related 
to currently fashionable political concerns do not count as political science. But this assertion would deprive the evidence in favor of the previous statement about the value of our intuitions about politics-a statement that is eminently political-of the status of the political. Rehfeld's stance on the status of old texts would mean that those scholars advancing political claims dependent upon politics' historicity would not be engaged in political science when they sought evidence to support their claims. Those scholars contesting the historicity of politics would likewise be removed from politics when they contest that evidence.

\section{CONCLUSION}

I have intentionally avoided the question of whether political theory can produce knowledge, even granting that much that is of political concern is not amenable to empirical analysis. I have spoken of "rigor" without further elaboration, except to agree with Rehfeld that the activity of political scientists should be research rather than mere self-expression or popular-press editorializing. Saying more on these subjects would require more space than is available and would require far more than an attack on the factvalue distinction (a topic seemingly of interest at present only to those scholars who wish to reject it), but also some substantive statements about justice.

Rehfeld's "offensive" defense of political theory involves the elimination of a good deal of what is currently called political theory, in addition to other subfields. While we agree that certain activities and research programs are not worth pursuing and "live and let live" is not a justification for their existence, Rehfeld's arguments for why some political theorists should continue to have an equal claim to graduate-assistant support and replacement lines while others should be cut off are founded upon a narrow conception of political science derived from a mistaken apprehension of social science. Bad political theory must be cleansed in the same way as bad anthropology or sociologynamely, by training graduate students not to put up with lazy arguments that flatter their unreflective political prejudices. Categorizing the subfield and then deciding which categories should stay and which should go is not a workable shortcut. While Rehfeld is correct that political theorists must have something positive to say about political science and their place within it, this mission calls for active outreach rather than retreat.

\section{NOTES}

1. This article was submitted just before I received the September 2010 Political Research Quarterly, which contains a mini-symposium on Timothy KaufmanOsborn's response to the Penn State controversy. Limitations of space prevent me from situating my concerns with Rehfeld's piece within this broader discussion, nor can I note all of the areas in which Rehfeld and I are in substantial agreement on this question.

2. For example, Rehfeld's focus on force is the outgrowth of a view that the question most in need of answering is why force over another human being is legit imate. An earlier view by Harold Lasswell that politics was the resolution of conflict over who gets what, when, and how was articulated at a time when the distribution of property seemed the thing most in need of explanation (Lasswell 1938). To argue that the truth of a religious belief is not a political question is to argue that it should not be a political question; for many people outside Western society, it is absurd to attempt to separate religion and politics.
3. I use the word "exceptional" because Rehfeld does. I do not mean that political science is unique in breaking these rules; as noted, I do not think that other disciplines actually follow them.

4. Economics is a diverse field, and I have no desire to impose a single definition upon it. Some departments say that economics deals with the allocation of scarce resources; others say that it deals with how people respond to (measurable) incentives; and still others refuse to define the discipline at all. My point is that economics deals with one aspect of human life that can be studied in isolation. Some prominent economists do apply the tools of economic analysis to other spheres of activity. To say that this practice is economics, however, would be to say that economics is a hypothesis rather than a field of inquiry.

\section{REFEREN C ES}

Alford, John R., and John R. Hibbing. 2004. "The Origin of Politics: An Evolutionary Theory of Political Behavior." Perspectives on Politics 2 (4): 707-23.

Ashcraft, Richard. 1986. Revolutionary Politics and Locke's "Two Treatises of Government." Princeton, NJ: Princeton University Press.

Axelrod, Robert. 2008. "Political Science and Beyond: Presidential Address to the American Political Science Association." Perspectives on Politics 6 (1): 3-9.

Doidge, Norman. 2010. "Neuroplasticity, Perfectibility, and Three Ideas of Nature." In Recovering Reason: Essays in Honor of Thomas L. Pangle, ed. Timothy Burns, 443-63. New York: Lexington.

Dunn, John. 1968. "The Identity of the History of Ideas." Philosophy 43 (164): 85-104.

-1969. The Political Thought of John Locke: An Historical Account of the Argument of the "Two Treatises of Government." Cambridge: Cambridge University Press.

Hatemi, Peter K., Sarah E. Medland, and Lindon J. Eaves. 2009. "Do Genes Contribute to the 'Gender Gap'?" Journal of Politics 71 (1): 262-76.

Klein, Julie Thomson. 1996. Crossing Boundaries: Knowledge, Disciplinarities, and Interdisciplinarities. Charlottesville: University Press of Virginia.

Lasswell, Harold D. 1938. Politics: Who Gets What, When, How. New York: McGraw-Hill

Lattuca, Lisa. 2001. Creating Interdisciplinarity. Nashville: Vanderbilt University Press.

Locke, John. 1983. A Letter Concerning Toleration. Ed. James Tully. Indianapolis, IN: Hackett.

MacDonald, Paul K. 2003. "Useful Fiction or Miracle Maker." American Political Science Review 97 (4): 551-65.

Mansfield, Harvey C. 2006. Manliness. New Haven: Yale University Press.

McDermott, Rose. 2004. “The Feeling of Rationality." Perspective on Politics 2 (4): 691-706.

Pangle, Thomas. 1988. The Spirit of Modern Republicanism: The Moral Vision of the American Founders and the Philosophy of John Locke. Chicago: University of Chicago Press.

Quattrone, George A., and Amos Tversky. 1988. "Contrasting Rational and Psychological Analyses of Political Choice." American Political Science Review 82 (3): 719-36.

Rehfeld, Andrew. 2010. "Offensive Political Theory." Perspective on Politics 8 (2): $465-86$.

Rhoten, Diana, and Andrew Parker. 2004. "Risks and Rewards of an Interdisciplinary Research Path." Science 306: 2,046.

Schiemann, John W. 2007. "Bizarre Beliefs and Rational Choices." Journal of Politics 69 (2): 511-24.

Schildkraut, Deborah J. 2004. "All Politics Is Psychological." Perspectives on Politics 2 (4): 807-19.

Skinner, Quentin. 1969. "Meaning and Understanding in the History of Ideas." History and Theory 8 (1): $3-53$.

Strauss, Leo. 1953. Natural Right and History. Chicago: University of Chicago Press.

Waldron, Jeremy. 2002. God, Locke, and Equality: Christian Foundations in Locke's Political Thought. Cambridge: Cambridge University Press.

Yolton, John. 1958. "Locke on the Law of Nature." Philosophical Review 67 (4): 477-98.

Zuckert, Michael. 2002. Launching Liberalism. Lawrence: University of Kansas Press. 